\title{
Levels of Cd (II), Mn (II), Pb (II), Cu (II), and Zn (II) in Common Buzzard (Buteo buteo) from Sicily (Italy) by Derivative Stripping Potentiometry
}

\author{
P. Licata, ${ }^{1}$ F. Naccari, ${ }^{1}$ V. Lo Turco, ${ }^{2}$ R. Rando, ${ }^{2}$ G. Di Bella, ${ }^{2}$ and G. Dugo ${ }^{3}$ \\ ${ }^{1}$ Department of Veterinary Public Health, Veterinary Medicine Faculty of Messina, University of Messina Polo S. S. Annunziata, \\ 98168 Messina, Italy \\ ${ }^{2}$ Department of Organic and Biological Chemistry, University of Messina, Salita Sperone 31, 98166 Messina, Italy \\ ${ }^{3}$ Department of Food and Environmental Science, Faculty of Science, University of Messina, Salita Sperone 31, 98166 Messina, Italy
}

Correspondence should be addressed to P. Licata, patrizia_licata@virgilio.it

Received 19 October 2009; Revised 11 January 2010; Accepted 1 April 2010

Academic Editor: Pavlos Kassomenos

Copyright (C) 2010 P. Licata et al. This is an open access article distributed under the Creative Commons Attribution License, which permits unrestricted use, distribution, and reproduction in any medium, provided the original work is properly cited.

\begin{abstract}
The purpose of this study was to determine the concentrations of heavy metals ( $\mathrm{Cd}, \mathrm{Pb}, \mathrm{Cu}, \mathrm{Mn}$, and $\mathrm{Zn}$ ) in different organs (liver, kidney, muscle, lung, skin, and feathers) of buzzards (Buteo buteo), utilized as a "biological indicator" for environmental contamination, from different areas of Sicily and to investigate the relationships between birds sex, age, and weight and metal levels in these samples. All samples of common buzzards were collected at the "Recovery Center of Wild Fauna" of Palermo, through the Zooprophilactic Institute. Potentiometric stripping analysis (PSA) was used to determine the content of Cd(II), Cu(II), Mn(II), $\mathrm{Pb}(\mathrm{II})$, and $\mathrm{Zn}$ (II) in bird tissues. For toxic metals, the highest levels of Pb were in liver and those of Cd in lung; $\mathrm{Zn}$ levels were higher than $\mathrm{Cu}$ and $\mathrm{Mn}$ in all tissues analyzed. The concentrations in liver, lung, kidney, and muscle could be considered as an indicative of chronic exposure to metals while the presence of metals in skin could be consequential to storing and elimination processes. The found concentrations of metals in the studied matrices required a highly sensitive method for their determination and a simple sample preparation procedure, and the proposed method was well suited for this purpose.
\end{abstract}

\section{Introduction}

Common buzzards are a diurnal bird of prey belonging to the Falconiformes kind to the Accipitridae family and at Buteo buteo species. It is European bird with a length between 50 and $60 \mathrm{~cm}$ and with wing span between 125 and $145 \mathrm{~cm}$ which makes it a prey of mean size. The female is greater than the male. Common buzzards live in the woods but usually catch in open territories. It catches little mammalian, rodents, rabbits, coleopteras, lizards, snakes, and little birds which are also considered "biological indicators" of heavy metals absorbed by ground or deposited by air; moreover, it has a primary role in the preservation of equilibrium of the natural ecosystem eating also the carrions [1].

Biomonitors such as plants and soil organisms are better for monitoring the uptake of environmental contaminants into the food web or pyramid of terrestrial ecosystems
[2]. Top predators can yield information over a large area around each sample site, not only regarding biovailability, but also about how, where, and when ecocontaminants are transferred within the food web. For ethical and legal reasons, however, top predators cannot be killed in quantities sufficient for biomonitoring. The use of sentinel species can provide interesting data to monitor the quality of the environment. Some species have biological habits that increase the likelihood of exposure to contaminants and can produce relevant information that would be missed if only water or soil were analyzed.

Heavy metals are ubiquitous elements present in nature and they must be considered important toxic contaminants because human activities have brought about a significant increase of their presence in the environment. They can easily enter the food chain and so cause possible toxic effects on humans and animals. 
Several studies concerning the environmental impact of heavy metals ( $\mathrm{Hg}, \mathrm{Cd}, \mathrm{Pb}, \mathrm{Cu}, \mathrm{Zn}, \mathrm{Mn}$, and $\mathrm{Fe}$ ) were made in organs and tissues (kidney, liver, muscle, feathers, skin, etc.) of various species of birds from Lombardia (north of Italy), from Marche and Umbria (centre of Italy), and from Campania (south of Italy). These data showed levels of $\mathrm{Cd}$ and $\mathrm{Pb}$ higher than our results in almost all samples analyzed [3-8].

The impact of heavy metals on the environment can be a serious threat for the stability of ecosystem $[9,10]$. In particular, lead and cadmium are potentially toxic and pose a serial risk for human health when enter the food chain [11, 12]. The use of lead shot, indeed, increases anthropogenic input of this metal into the environment and causes a very specific pollution problem, resulting in considerable avian mortality. Primary lead toxicosis is prevalent among water birds which ingest lead shot by mistaking it for grit or seeds [1].

Cadmium has been described as one of the most dangerous trace elements in food and in the environment, not only for its high toxicity but also for its persistence. Atmospheric cadmium deposited on the earth's crust can be absorbed or retained by soil particles and become part of biological structures.

Regarding copper, manganese and zinc are essential metals for human and animals, since they are involved in many physiological processes and are important micronutrients in human diet. Particularly, manganese plays an important role in the metabolism of proteins, carbohydrates, lipids, and in the production of steroids sexual hormones; moreover, it is the cofactor of enzymes such as RNA synthetase, glutamine synthetase, pyruvate decarboxylase, Mn-superoxido dismutase, and arginase [13].

At present, there are no data concerning the concentrations of heavy metals from the area of Sicily. Therefore, the purpose of this study was to determine the concentrations of heavy metals $(\mathrm{Cd}, \mathrm{Pb}, \mathrm{Cu}, \mathrm{Mn}$, and $\mathrm{Zn})$ in different organs (liver, kidney, muscle, lung, skin, and feathers) of buzzards (Buteo buteo), utilized as a "biological indicator" for environmental contamination, from different areas of Sicily and to investigate the relationships between birds sex, age and weight, and metal levels in these samples.

\section{Materials and Methods}

2.1. Samples. During the period of April and December 200611 common buzzards (Buteo buteo) were collected from different areas of Sicily. Almost all little owls were taken during the summer, whereas the majority of the buzzards were gathered during winter. All the raptors came from Center of Recupero Fauna Selvatica of Palermo. The birds had been brought to the Center alive but injured or debilitated for various reasons. The main cause of death was determined by examining the birds macroscopically and, when necessary, radiological, histological, or toxicological analysis was done [2]. These different causes of death were classified as different kinds of trauma. Frequently the birds were injured by collision with a vehicle or with power lines
TABLe 1: Characteristics of common buzzards (Buteo buteo) analyzed.

\begin{tabular}{lccc}
\hline Samples & Sex & Age & Weight $(\mathrm{g})$ \\
\hline 1 & $\mathrm{M}$ & juveniles & 715 \\
2 & $\mathrm{~F}$ & adult & 830 \\
3 & $\mathrm{~F}$ & adult & 745 \\
4 & $\mathrm{M}$ & juveniles & 525 \\
5 & $\mathrm{~F}$ & adult & 720 \\
6 & $\mathrm{~F}$ & juveniles & 600 \\
7 & $\mathrm{M}$ & adult & 830 \\
8 & $\mathrm{M}$ & juveniles & 750 \\
9 & $\mathrm{M}$ & adult & 620 \\
10 & $\mathrm{~F}$ & adult & 800 \\
11 & $\mathrm{~F}$ & juveniles & 550 \\
\hline
\end{tabular}

or by lead shot. In general, the main causes of admission in the Centro were fractures and luxations due to traumas. In the postmortem examination, sex, age, and weight were determined (Table 1). The following data were gathered for each bird: sex, age, weight, cause of death, area of origin, data of arrival, and data of death. The 11 (6 females and 5 males) common buzzards comprised 5 juveniles and 6 adults (Table 1). The following samples were taken from each corpse: liver, kidneys, pectoral muscle, lungs, and skin. The preparation of samples was carried out taking care to avoid contamination and losses as much as possible: sterile scalpels and surgical tools cleaned or substituted for each bird were used together with rubber latex gloves. The working surface was also cleaned after each operation. The samples were handled in away to avoid any contact with external surfaces, placed individually in plastic bags, and stored at $-20^{\circ} \mathrm{C}$ until analysis.

2.2. Instrument. Analyses were carried out on a PSA ION 3 potentiometric stripping analyzer (Steroglass, S. Martino in Campo, Perugia, Italy), which was controlled by NEOTES 2.0.1 software (Steroglass) run on an IBM-compatible personal computer. The instrument was equipped with a conventional three-electrode cell and was used for the analysis of $\mathrm{Cd}(\mathrm{II}), \mathrm{Cu}(\mathrm{II}), \mathrm{Mn}(\mathrm{II}), \mathrm{Pb}(\mathrm{II})$, and $\mathrm{Zn}(\mathrm{II})$ in common buzzards samples. The working electrode was a glassy carbon electrode coated with a thin mercury film; the reference electrode was an $\mathrm{Ag} / \mathrm{AgCl}$ electrode $(3 \mathrm{M} \mathrm{KCl})$, and a platinum wire auxiliary electrode was used.

2.3. Reagents. Ultra pure hydrochloric acid (34\%-37\%), $\mathrm{Hg}$ (II) $\left(1000 \mathrm{mgKg}^{-1}, 1 \mathrm{M}\right.$ in hydrochloric acid) and $\mathrm{Cd}(\mathrm{II})$, $\mathrm{Cu}(\mathrm{II}), \mathrm{Mn}(\mathrm{II}), \mathrm{Pb}(\mathrm{II}), \mathrm{Zn}(\mathrm{II})\left(1000 \mathrm{mgKg}^{-1} 0.5 \mathrm{~N}\right.$ in $\left.\mathrm{HNO}_{3}\right)$ standard solutions were purchased from Panreac (Barcelona, Spain). Ultra pure $\mathrm{H}_{2} \mathrm{O}_{2} 35 \%$, used in the extraction procedure, was purchased from Carlo Erba Reagenti (Milan, Italy). Methanol was obtained by Carlo Erba Reagenti (Milan, Italy). The $0.5 \mathrm{M}$ ammonia buffer ( $\mathrm{pH}$ 9.5) was purchased from Panreac (Barcelona, Spain). Ultra pure water $\left(18.2 \mathrm{M} \Omega \mathrm{cm}^{-1}\right)$ was obtained by Carlo Erba Reagenti (Milan, Italy). The accuracy of the stripping potentiometer 
TABle 2: ${ }^{(a)}$ Repeatability (rsd\%), ${ }^{(b)} \mathrm{LOD}\left(\mu \mathrm{g} / \mathrm{Kg}\right.$ ), and ${ }^{(\mathrm{c})}$ accuracy (\%) for the determination of Cd(II), $\mathrm{Cu}(\mathrm{II}), \mathrm{Pb}(\mathrm{II}), \mathrm{Mn}(\mathrm{II})$, and $\mathrm{Zn}(\mathrm{II})$ by derivative stripping potentiometry in samples of Buteo buteo.

\begin{tabular}{|c|c|c|c|c|c|}
\hline & Liver & Kidney & Muscle & Lungs & Skin \\
\hline \multirow{3}{*}{ Cd(II) } & (a) 1.30 & 4.01 & 2.30 & 3.60 & 4.20 \\
\hline & (b) 0.50 & 0.40 & 1.00 & 0.72 & 0.30 \\
\hline & (c) 94.4 & 93.8 & 95.1 & 96.4 & 94.0 \\
\hline \multirow{3}{*}{$\mathrm{Cu}(\mathrm{II})$} & (a) 4.10 & 3.70 & 2.50 & 1.10 & 3.90 \\
\hline & (b) 2.00 & 0.71 & 2.81 & 1.30 & 1.20 \\
\hline & (c) 95.0 & 97.2 & 93.0 & 97.4 & 98.8 \\
\hline \multirow{3}{*}{$\mathrm{Pb}(\mathrm{II})$} & (a) 1.70 & 2.82 & 0.90 & 3.02 & 2.80 \\
\hline & (b) 2.00 & 0.71 & 2.30 & 1.18 & 0.40 \\
\hline & (c) 92.5 & 96.6 & 98.0 & 95.2 & 98.4 \\
\hline \multirow{3}{*}{$\operatorname{Mn}(\mathrm{II})$} & (a) 2.91 & 0.70 & 1.80 & 0.80 & 2.30 \\
\hline & (b) 2.70 & 2.51 & 1.90 & 1.60 & 2.30 \\
\hline & (c) 97.5 & 97.1 & 93.9 & 95.7 & 97.3 \\
\hline \multirow{3}{*}{$\mathrm{Zn}(\mathrm{II})$} & (a) 4.10 & 1.01 & 2.72 & 2.60 & 1.61 \\
\hline & (b) 2.80 & 1.70 & 1.50 & 2.90 & 2.02 \\
\hline & (c) 95.2 & 98.0 & 98.9 & 93.0 & 97.7 \\
\hline
\end{tabular}

and the reliability of the methods described were tested with reference matrices of pork liver (NRMGBW08551) (LGC Promochem Milan, Italy).

2.4. Sample Preparation. All glassware was cleaned prior to use by soaking in $10 \% \mathrm{v} / \mathrm{v}$ for 12 hours and rinsed with ultra-pure water. Birds samples were dried in a $100^{\circ} \mathrm{C}$ oven. An exactly weighing aliquot of each sample was separately placed into teflon beakers and digested with $10.0 \mathrm{~mL} 35 \% \quad \mathrm{H}_{2} \mathrm{O}_{2}$ at $45^{\circ} \mathrm{C}$ for 1 hour. The digested samples were dissolved in $10.0 \mathrm{~mL}$ of $37 \% \mathrm{HCl}$ at $70^{\circ} \mathrm{C}$ for about 1 hour under magnetic stirring in order to ensure that all metals present remain in unbound-free forms. The dissolved sample was filtered through an acid precleaned $0.45 \mu \mathrm{m}$ membrane and then it was filtered on a carbon column previously activated by $2.0 \mathrm{~mL}$ of methanol followed by $2.0 \mathrm{~mL}$ of ultra-pure water to remove any residue of organic matter. The filtrates appeared colorless. Derivative stripping potentiometry allowed the direct determination of $\mathrm{Cd}(\mathrm{II})$, $\mathrm{Cu}(\mathrm{II}), \mathrm{Mn}(\mathrm{II}), \mathrm{Pb}(\mathrm{II})$, and $\mathrm{Zn}(\mathrm{II})$.

2.5. Mercury Film Formation (Plating). Prior to each new experiment, a fresh mercury film was plated onto the glassy carbon surface of the working electrode by electrolyzing $20 \mathrm{~mL}$ of a $1000 \mathrm{mg} \mathrm{Hg}$ (II) $\mathrm{Kg}^{-1}$ standard solution at $-950 \mathrm{mV}$ for 1 minute. After each analysis, the used mercury film was removed by wiping the electrode surface with filter paper. The electrodes were stored in ultra-pure water.

2.6. Derivative Potentiometric Stripping Analysis (dPSA). $\mathrm{Cd}(\mathrm{II}), \mathrm{Cu}(\mathrm{II}), \mathrm{Pb}(\mathrm{II})$, and $\mathrm{Zn}(\mathrm{II})$ can be simultaneously determined in common buzzard tissues, by placing into the electrochemical cell $2.0 \mathrm{~mL}$ of sample, $10.0 \mathrm{~mL}$ of ultrapure water, $1.0 \mathrm{~mL}$ of $1000 \mathrm{mg} \mathrm{Hg}$ (II) $\mathrm{Kg}^{-1}$ standard solution as the oxidant agent [14]. The $\mathrm{pH}$ of the sample was in the range of 1.8-2.0. The stirred electrolysis was executed at $-1200 \mathrm{mV}$ for 120 seconds, then the potential was scanned towards less negative values (until $0 \mathrm{mV}$ ) at a scan rate of $10 \mathrm{mV} / \mathrm{s}$; the $\mathrm{Zn}(\mathrm{II}), \mathrm{Cd}(\mathrm{II}), \mathrm{Pb}(\mathrm{II})$, and $\mathrm{Cu}(\mathrm{II})$ stripping peaks were respectively registered at $-960 \mathrm{mV},-650 \mathrm{mV},-470 \mathrm{mV}$, and $-280 \mathrm{mV}$. The quantitative analysis was executed by the multiple point standard additions method by adding twice $0.2 \mathrm{~mL}$ of $5.0 \mathrm{mgKg}^{-1} \mathrm{Zn}$ (II) and $\mathrm{Cu}(\mathrm{II})$ standard solutions, and $0.2 \mathrm{~mL}$ of $1.0 \mathrm{mgKg}^{-1} \mathrm{Cd}(\mathrm{II})$ and $\mathrm{Pb}(\mathrm{II})$ standard solutions. The analysis lasted 40 minutes. For Mn analysis, after the plating of the working electrode with mercury, $10.0 \mu \mathrm{L}$ of sample extract were put into the electrochemical cell together with $0.20 \mathrm{~mL}$ of $0.5 \mathrm{M}$ ammonia-ammonium chloride buffer ( $\mathrm{pH} 9.5$ ), $19.0 \mathrm{~mL}$ of ultra-pure water, $0.1 \mathrm{~mL}$ of $\mathrm{Hg}$ (II) $1000 \mathrm{mgKg}^{-1}$, and deoxygenated for 5 minutes by $\mathrm{N}_{2}$ purging. The best electrochemical conditions were optimized by fixing the final acquisition potential and the cleaning potential, respectively at $-500 \mathrm{mV}$ and $-1500 \mathrm{mV}$, and fixing the deposition time at $-120 \mathrm{~s}$; the solution was stirred at $1000 \mathrm{rpm}$. The manganese stripping peak was registered around $-1460 \mathrm{mV}$. The quantitative analysis was done by the multiple-point standard additions method. Optimum precision and accuracy were obtained with the addition of two $0.05 \mathrm{~mL}$ aliquots of a $1.0 \mathrm{mgL}^{-1}$ standard solution of $\mathrm{Mn}$ (II) and performing the measurements five times. In the optimized electrochemical conditions, the manganese analysis lasted about 30 minutes.

\section{Results}

3.1. Method Performances. The extraction method repeatability was calculated by extracting each matrices three times and determining each metal four times in the same extract: the repeatability is represented by the mean r.s.d.\% $(n=$ 12) of all the measurements and ranged from 0.70 to 4.20 rsd\% (Table 2). The limit of detection (LOD) of all the 
TABLE 3: Heavy metal concentrations ( $\mu \mathrm{g} / \mathrm{g})$ in liver of Buteo buteo; each result is the mean of three determinations \pm standard deviation.

\begin{tabular}{lccccc}
\hline Liver & $\mathrm{Cd}(\mathrm{II})$ & $\mathrm{Pb}(\mathrm{II})$ & $\mathrm{Cu}(\mathrm{II})$ & $\mathrm{Mn}(\mathrm{II})$ & $\mathrm{Zn}(\mathrm{II})$ \\
\hline $\mathbf{1}$ & $0.30 \pm 0.10$ & $19.55 \pm 2.00$ & $35.85 \pm 3.10$ & $14.98 \pm 1.50$ & $138.00 \pm 10.60$ \\
$\mathbf{2}$ & $0.25 \pm 0.11$ & $10.86 \pm 1.20$ & $24.70 \pm 2.40$ & $7.15 \pm 0.71$ & $107.00 \pm 9.12$ \\
$\mathbf{3}$ & $0.15 \pm 0.10$ & $15.25 \pm 1.45$ & $45.95 \pm 4.60$ & $9.55 \pm 0.95$ & $144.25 \pm 10.75$ \\
$\mathbf{4}$ & $0.31 \pm 0.12$ & $18.24 \pm 1.83$ & $32.47 \pm 3.23$ & $8.48 \pm 0.80$ & $136.93 \pm 10.50$ \\
$\mathbf{5}$ & $0.18 \pm 0.09$ & $13.70 \pm 1.32$ & $50.18 \pm 5.00$ & $7.57 \pm 0.71$ & $134.33 \pm 10.46$ \\
$\mathbf{6}$ & $0.10 \pm 0.09$ & $11.30 \pm 1.05$ & $38.28 \pm 3.83$ & $7.75 \pm 0.72$ & $92.15 \pm 9.13$ \\
$\mathbf{7}$ & $0.17 \pm 0.10$ & $10.90 \pm 1.00$ & $47.75 \pm 4.55$ & $7.80 \pm 0.72$ & $140.13 \pm 11.38$ \\
$\mathbf{8}$ & $0.34 \pm 0.08$ & $19.90 \pm 1.10$ & $27.50 \pm 3.40$ & $10.50 \pm 0.70$ & $111.20 \pm 9.55$ \\
$\mathbf{9}$ & $0.18 \pm 0.15$ & $12.50 \pm 1.80$ & $38.30 \pm 3.24$ & $9.20 \pm 0.30$ & $98.90 \pm 10.65$ \\
$\mathbf{1 0}$ & $0.27 \pm 0.10$ & $12.90 \pm 1.35$ & $24.90 \pm 2.30$ & $7.70 \pm 1.00$ & $137.14 \pm 11.20$ \\
$\mathbf{1 1}$ & $0.30 \pm 0.18$ & $17.25 \pm 1.00$ & $49.90 \pm 4.60$ & $8.40 \pm 0.90$ & $99.60 \pm 10.25$ \\
\hline $\mathbf{M} \pm$ sd & $\mathbf{0 . 2 3} \pm \mathbf{0 . 1 1}$ & $\mathbf{1 4 . 7 6} \pm \mathbf{1 . 3 7}$ & $\mathbf{3 7 . 8 0} \pm \mathbf{3 . 6 6}$ & $\mathbf{9 . 0 0} \pm \mathbf{0 . 8 2}$ & $\mathbf{1 2 1 . 7 8 \pm \mathbf { 1 0 . 3 3 }}$ \\
\hline
\end{tabular}

TABLE 4: Heavy metal concentrations $(\mu \mathrm{g} / \mathrm{g})$ in kidney of Buteo buteo; each result is the mean of three determinations \pm standard deviation.

\begin{tabular}{lccccc}
\hline Kidney & $\mathrm{Cd}(\mathrm{II})$ & $\mathrm{Pb}(\mathrm{II})$ & $\mathrm{Cu}(\mathrm{II})$ & $\mathrm{Mn}(\mathrm{II})$ & $\mathrm{Zn}(\mathrm{II})$ \\
\hline $\mathbf{1}$ & $0.45 \pm 0.12$ & $0.58 \pm 0.13$ & $7.86 \pm 0.75$ & $1.60 \pm 0.20$ & $65.82 \pm 5.50$ \\
$\mathbf{2}$ & $0.69 \pm 0.13$ & $0.40 \pm 0.13$ & $7.25 \pm 0.70$ & $1.55 \pm 0.18$ & $55.60 \pm 5.01$ \\
$\mathbf{3}$ & $0.50 \pm 0.11$ & $0.44 \pm 0.14$ & $13.13 \pm 1.11$ & $1.03 \pm 0.10$ & $86.10 \pm 7.60$ \\
$\mathbf{4}$ & $0.35 \pm 0.10$ & $0.29 \pm 0.09$ & $8.39 \pm 0.82$ & $1.60 \pm 0.20$ & $109.67 \pm 9.10$ \\
$\mathbf{5}$ & $0.70 \pm 0.13$ & $0.35 \pm 0.11$ & $9.10 \pm 0.90$ & $0.95 \pm 0.10$ & $45.05 \pm 4.15$ \\
$\mathbf{6}$ & $0.53 \pm 0.13$ & $0.50 \pm 0.11$ & $8.03 \pm 0.80$ & $1.72 \pm 0.22$ & $33.20 \pm 3.40$ \\
$\mathbf{7}$ & $0.40 \pm 0.12$ & $0.22 \pm 0.10$ & $11.50 \pm 0.95$ & $1.48 \pm 0.19$ & $61.66 \pm 5.09$ \\
$\mathbf{8}$ & $0.68 \pm 0.10$ & $0.42 \pm 0.14$ & $12.35 \pm 1.80$ & $0.98 \pm 0.80$ & $80.50 \pm 6.90$ \\
$\mathbf{9}$ & $0.45 \pm 0.16$ & $0.20 \pm 0.08$ & $9.70 \pm 1.20$ & $1.58 \pm 0.20$ & $66.10 \pm 4.20$ \\
$\mathbf{1 0}$ & $0.55 \pm 0.11$ & $0.55 \pm 0.18$ & $10.30 \pm 1.70$ & $1.75 \pm 0.18$ & $44.77 \pm 4.10$ \\
$\mathbf{1 1}$ & $0.38 \pm 0.15$ & $0.32 \pm 0.12$ & $9.90 \pm 0.90$ & $1.30 \pm 0.10$ & $\mathbf{3} .30 \pm 3.50$ \\
\hline $\mathbf{M} \pm$ sd & $\mathbf{0 . 5 2} \pm \mathbf{0 . 1 2}$ & $\mathbf{0 . 3 9} \pm \mathbf{0 . 1 2}$ & $\mathbf{9 . 7 7} \pm \mathbf{1 . 0 6}$ & $\mathbf{1 . 4 1} \pm \mathbf{0 . 2 2}$ & $\mathbf{6 2 . 2 5} \pm \mathbf{5 . 3 2}$ \\
\hline
\end{tabular}

studied metals was evaluated using the expression $3 \sigma / S$ [15]: $\sigma$ indicated the standard deviation of the response (set at $200 \mathrm{~ms} / \mathrm{V}$ ) and $S$ the sensitivity expressed as the slope of the calibration curves of each analyte. Table 2 shows the obtained LOD ranged between 0.30 and $2.81 \mu \mathrm{gKg}^{-1}$. Carrying out the potentiometric determination of $\mathrm{Cu}$ (II), $\mathrm{Pb}(\mathrm{II}), \mathrm{Cd}(\mathrm{II}), \mathrm{Mn}(\mathrm{II})$, and $\mathrm{Zn}(\mathrm{II})$, a good linearity was obtained in the range of concentrations $0.0003-6.0 \mathrm{mgKg}^{-1}$ $(R \geq 0.995)$. To test the accuracy of the stripping potentiometer and the reliability of the methods described, recoveries from reference matrices of pork liver, subjected to the extraction procedure already described, were carried out (Table 2). The obtained results ranged from $92.5 \%$ to $98.9 \%$ (Table 2).

3.2. Analytical Application. Concentrations $\left(\mu \mathrm{gg}^{-1}\right)$, range, and mean values \pm sd of each heavy metals found in eleven samples (liver, kidney, muscle, lung, and skin, resp.) of common buzzards (Buteo buteo) from different areas of Sicily were reported in Tables 3, 4, 5, 6, and 7 .
Results obtained have showed the presence of various metals in all samples analyzed. In particular, the highest levels of $\mathrm{Pb}(\mathrm{II}), \mathrm{Cu}(\mathrm{II}), \mathrm{Mn}(\mathrm{II})$, and $\mathrm{Zn}(\mathrm{II})$ were found in liver and those of $\mathrm{Cd}(\mathrm{II})$ in lung samples. Concentrations of zinc were more higher than other metals in all samples analyzed.

The statistical comparisons among the heavy metal concentrations reveal that $\mathrm{Pb}$ and $\mathrm{Zn}$ levels are more significant $(P<.01)$ in liver than in all other samples.

No significant correlation between all heavy metals concentrations and sex, age, and weight of Buteo buteo analyzed was observed.

\section{Discussions}

Derivative stripping potentiometry is a valid technique for monitoring heavy metals pollution in the environment. It has many advantages with respect to the conventional methods as AAS or ICP-MS, both from the economical and the 
TABle 5: Heavy metal concentrations $(\mu \mathrm{g} / \mathrm{g})$ in muscle of Buteo buteo; each result is the mean of three determinations \pm standard deviation.

\begin{tabular}{lccccc}
\hline Muscle & $\mathrm{Cd}(\mathrm{II})$ & $\mathrm{Pb}(\mathrm{II})$ & $\mathrm{Cu}(\mathrm{II})$ & $\mathrm{Mn}(\mathrm{II})$ & $\mathrm{Zn}(\mathrm{II})$ \\
\hline $\mathbf{1}$ & $0.05 \pm 0.04$ & $0.90 \pm 0.15$ & $19.10 \pm 1.94$ & $0.80 \pm 0.13$ & $65.53 \pm 6.15$ \\
$\mathbf{2}$ & $0.10 \pm 0.10$ & $0.75 \pm 0.12$ & $23.50 \pm 2.28$ & $0.81 \pm 0.13$ & $48.90 \pm 5.00$ \\
$\mathbf{3}$ & $0.20 \pm 0.12$ & $0.55 \pm 0.11$ & $40.92 \pm 4.00$ & $4.20 \pm 0.20$ & $45.54 \pm 4.45$ \\
$\mathbf{4}$ & $0.09 \pm 0.09$ & $0.60 \pm 0.14$ & $44.05 \pm 4.35$ & $0.86 \pm 0.15$ & $55.60 \pm 5.50$ \\
$\mathbf{5}$ & $0.03 \pm 0.03$ & $0.85 \pm 0.13$ & $32.67 \pm 3.15$ & $0.90 \pm 0.16$ & $78.55 \pm 7.63$ \\
$\mathbf{6}$ & $0.08 \pm 0.04$ & $1.10 \pm 0.18$ & $45.80 \pm 4.44$ & $0.72 \pm 0.13$ & $32.60 \pm 3.18$ \\
$\mathbf{7}$ & $0.18 \pm 0.10$ & $0.95 \pm 0.13$ & $26.05 \pm 2.50$ & $0.65 \pm 0.14$ & $36.55 \pm 3.59$ \\
$\mathbf{8}$ & $0.10 \pm 0.09$ & $0.99 \pm 0.16$ & $20.10 \pm 1.90$ & $0.95 \pm 0.15$ & $70.65 \pm 7.00$ \\
$\mathbf{9}$ & $0.16 \pm 0.05$ & $0.65 \pm 0.15$ & $24.30 \pm 3.00$ & $1.10 \pm 0.12$ & $44.25 \pm 4.49$ \\
$\mathbf{1 0}$ & $0.15 \pm 0.08$ & $1.05 \pm 0.12$ & $40.90 \pm 4.25$ & $0.90 \pm 0.18$ & $33.60 \pm 3.50$ \\
$\mathbf{1 1}$ & $0.20 \pm 0.12$ & $0.98 \pm 0.10$ & $32.70 \pm 3.60$ & $1.00 \pm 0.20$ & $60.35 \pm 5.90$ \\
\hline $\mathbf{M} \pm$ sd & $\mathbf{0 . 1 2} \pm \mathbf{0 . 0 8 6}$ & $\mathbf{0 . 8 5} \pm \mathbf{0 . 1 3}$ & $\mathbf{3 1 . 8 3} \pm \mathbf{3 . 2 2}$ & $\mathbf{0 . 9 0} \pm \mathbf{0 . 1 5}$ & $\mathbf{5 2 . 0 1} \pm \mathbf{5 . 1 3}$ \\
\hline
\end{tabular}

TABLE 6: Heavy metal concentrations ( $\mu \mathrm{g} / \mathrm{g})$ in lung of Buteo buteo; each result is the mean of three determinations \pm standard deviation.

\begin{tabular}{|c|c|c|c|c|c|}
\hline Lungs & $\mathrm{Cd}(\mathrm{II})$ & $\mathrm{Pb}(\mathrm{II})$ & $\mathrm{Cu}(\mathrm{II})$ & $\operatorname{Mn}(\mathrm{II})$ & $\mathrm{Zn}(\mathrm{II})$ \\
\hline 1 & $0.62 \pm 0.10$ & $0.73 \pm 0.12$ & $6.52 \pm 0.50$ & $1.65 \pm 0.30$ & $105.0 \pm 9.55$ \\
\hline 2 & $0.43 \pm 0.13$ & $0.38 \pm 0.13$ & $4.15 \pm 0.35$ & $0.54 \pm 0.15$ & $52.70 \pm 5.12$ \\
\hline 3 & $0.60 \pm 0.14$ & $0.44 \pm 0.15$ & $5.20 \pm 0.40$ & $0.75 \pm 0.18$ & $50.60 \pm 5.00$ \\
\hline 4 & $0.86 \pm 0.15$ & $1.35 \pm 0.25$ & $14.28 \pm 1.20$ & $1.89 \pm 0.20$ & $92.56 \pm 9.00$ \\
\hline 5 & $0.47 \pm 0.10$ & $1.00 \pm 0.20$ & $12.15 \pm 0.80$ & $1.60 \pm 0.16$ & $100.5 \pm 8.60$ \\
\hline 6 & $0.74 \pm 0.16$ & $0.80 \pm 0.16$ & $7.30 \pm 0.60$ & $0.56 \pm 0.12$ & $60.50 \pm 4.90$ \\
\hline 7 & $0.56 \pm 0.12$ & $1.10 \pm 0.18$ & $4.25 \pm 0.45$ & $1.80 \pm 0.21$ & $83.10 \pm 8.00$ \\
\hline 8 & $0.61 \pm 0.13$ & $0.55 \pm 0.14$ & $12.15 \pm 0.90$ & $0.80 \pm 0.14$ & $74.60 \pm 7.60$ \\
\hline 9 & $0.85 \pm 0.15$ & $0.70 \pm 0.12$ & $6.45 \pm 0.50$ & $0.92 \pm 0.18$ & $104.0 \pm 9.50$ \\
\hline 10 & $0.63 \pm 0.11$ & $1.20 \pm 0.22$ & $14.20 \pm 1.10$ & $1.00 \pm 0.20$ & $90.30 \pm 8.40$ \\
\hline 11 & $0.48 \pm 0.12$ & $0.60 \pm 0.18$ & $11.80 \pm 0.75$ & $1.70 \pm 0.30$ & $55.09 \pm 6.20$ \\
\hline$M \pm s d$ & $0.62 \pm 0.13$ & $0.80 \pm 0.17$ & $8.95 \pm 0.69$ & $1.20 \pm 0.19$ & $78.95 \pm 7.44$ \\
\hline
\end{tabular}

TABle 7: Heavy metal concentrations $(\mu \mathrm{g} / \mathrm{g})$ in skin of Buteo buteo; each result is the mean of three determinations \pm standard deviation.

\begin{tabular}{|c|c|c|c|c|c|}
\hline Skin & $\mathrm{Cd}(\mathrm{II})$ & $\mathrm{Pb}(\mathrm{II})$ & $\mathrm{Cu}(\mathrm{II})$ & $\mathrm{Mn}(\mathrm{II})$ & $\mathrm{Zn}(\mathrm{II})$ \\
\hline 1 & $0.10 \pm 0.08$ & $1.60 \pm 0.21$ & $7.97 \pm 0.80$ & $3.15 \pm 0.30$ & $57.50 \pm 5.00$ \\
\hline 2 & $0.12 \pm 0.09$ & $1.75 \pm 0.22$ & $8.73 \pm 0.82$ & $0.95 \pm 0.12$ & $46.65 \pm 4.50$ \\
\hline 3 & $0.09 \pm 0.08$ & $2.46 \pm 0.23$ & $13.46 \pm 1.25$ & $2.20 \pm 0.25$ & $41.10 \pm 4.10$ \\
\hline 4 & $0.07 \pm 0.05$ & $0.95 \pm 0.12$ & $7.82 \pm 0.75$ & $2.55 \pm 0.27$ & $59.72 \pm 5.10$ \\
\hline 5 & $0.03 \pm 0.04$ & $1.56 \pm 0.18$ & $9.24 \pm 0.93$ & $1.96 \pm 0.20$ & $55.76 \pm 5.01$ \\
\hline 6 & $0.04 \pm 0.03$ & $2.69 \pm 0.27$ & $8.15 \pm 0.80$ & $2.30 \pm 0.22$ & $79.02 \pm 6.50$ \\
\hline 7 & $0.18 \pm 0.10$ & $1.85 \pm 0.25$ & $10.65 \pm 1.15$ & $1.52 \pm 0.16$ & $81.10 \pm 7.51$ \\
\hline 8 & $0.08 \pm 0.03$ & $2.15 \pm 0.24$ & $12.60 \pm 1.10$ & $1.90 \pm 0.26$ & $50.20 \pm 5.50$ \\
\hline 9 & $0.11 \pm 0.05$ & $1.60 \pm 0.20$ & $8.80 \pm 0.70$ & $2.50 \pm 0.18$ & $71.15 \pm 6.80$ \\
\hline 10 & $0.17 \pm 0.09$ & $1.74 \pm 0.19$ & $10.65 \pm 0.90$ & $1.99 \pm 0.20$ & $65.70 \pm 5.21$ \\
\hline 11 & $0.18 \pm 0.10$ & $2.10 \pm 0.22$ & $12.15 \pm 1.20$ & $0.92 \pm 0.15$ & $44.00 \pm 4.40$ \\
\hline$M \pm s d$ & $0.11 \pm 0.07$ & $1.86 \pm 0.21$ & $10.02 \pm 0.94$ & $1.99 \pm 0.21$ & $59.26 \pm 5.42$ \\
\hline
\end{tabular}


analytical points of view. The costs of the equipment are low and its small dimensions allow its transport for field analysis. Derivative potentiometric stripping analysis (dPSA) enables the simultaneous determination of $\mathrm{Cd}, \mathrm{Cu}, \mathrm{Pb}, \mathrm{Mn}$, and $\mathrm{Zn}$ levels. The high sensitivity of these methods allow to detect heavy metals concentration lower than $0.5 \mathrm{ppb}$. In this paper, derivative stripping potentiometry is used to assess $\mathrm{Cd}, \mathrm{Cu}$, $\mathrm{Pb}, \mathrm{Mn}$, and $\mathrm{Zn}$ bioaccumulation in tissues of Buteo buteo from Sicily.

Results obtained showed among toxic metals the presence of high concentrations of $\mathrm{Pb}$ above all in liver samples following by feather and lung samples in all poiane examined. Regarding essential metals, $\mathrm{Zn}$ levels are resulted more higher than $\mathrm{Cu}$ and $\mathrm{Mn}$. Moreover, the range concentrations of $\mathrm{Cd}(\mathrm{II}), \mathrm{Pb}(\mathrm{II}), \mathrm{Cu}(\mathrm{II}), \mathrm{Mn}(\mathrm{II})$, and $\mathrm{Zn}(\mathrm{II})$ in all samples analyzed were not correlated with sex, age, and weight of Buteo buteo. These data are in according with those reported by other authors in birds from centre Italy $[7,8]$ and south Italy $[5,6]$, but lower than data reported by authors in birds from north Italy $[1,3,4]$.

Levels of heavy metals examined in liver, kidney, lungs, and muscle can be considered indicative of chronic exposure, whereas the presence of metals in the feathers could be due to stored or metals deposition processes [16]. Acute lead poisoning can be ensured in the case of ingestion of a large number of shot, and birds usually die within a few days. Shots are the only widespread source of lead poisoning in raptors as they can be carried in the flesh of dead or injured prey. Generally birds die of chronic lead poisoning following ingestion of a smaller number of shots $[17,18]$.

Locke and Friend [19] reported that lead poisoning has been documented in a sufficiently wide variety of birds to consider all birds as being susceptible to intoxication after ingesting and retaining lead shot.

Feathers can play the role of both storing and of eliminating metals. Metal levels in feathers reflect blood levels during the short period of feather growth, when the is connected with blood and metals which are incorporated in the keratin structure $[20,21]$. This is not the only factor to take into account, though indeed, feathers can also measure external contamination. The toxicological consequences of lead shot ingestion are dependent on different variables condition of the animal (sex, age, diet, and climate).

Common buzzards feed on a wide range of prey, particularly small mammals and invertebrates, for example, earthworms (Lumbricidae), sometimes reptiles, amphibians, and small birds. Buzzards act often as scavengers and to be exposed to lead shot in small game species. This could explain the correlation between concentrations of lead in liver in buzzards since such tissues are the first targets of metal and are an index of recent exposure [2].

Cd concentrations in birds are generally reported to be highest in kidney, lower in liver, and very low in muscle [22]. Our study have showed the presence of low Cd levels in muscle and feathers as reported by other authors $[22,23]$. Cadmium content of feathers can be clearly ascribed to either the share deposited in growing feathers from the blood or to that on feather surface of atmospheric aqueous origin [24].
In conclusions, our data suggest a condition of chronic exposure for lead but there is not a condition of high exposure to cadmium in buzzard.

Our data deserve particular attention not only for their significance but especially because they were recorded in Sicily, a region with a very low risk of environmental pollution due to the shortage of industries. To better biomonitor the environmental contamination, it would be worthwhile to continue measuring $\mathrm{Cd}, \mathrm{Cu}, \mathrm{Pb}$, and $\mathrm{Zn}$ to extend the scope of monitoring to other heavy metals such as $\mathrm{Cr}, \mathrm{Hg}$, and Al.

Moreover, for the sake of food safety, we will propose to extend our investigations regarding the heavy metal concentrations in various avian species, poultry, and food producing animals from the same areas of Sicily to confirm the absence of toxicological risks in this region with a very low impact of environmental pollution due to the shortage of industries.

\section{References}

[1] A. Battaglia, S. Ghidini, G. Campanini, and R. Spaggiari, "Heavy metal contamination in little owl (Athene noctua) and common buzzard (Buteo buteo) from northern Italy," Ecotoxicology and Environmental Safety, vol. 60, no. 1, pp. 6166, 2005.

[2] L. P. Jager, F. V. J. Rijnierse, H. Esselink, and A. J. Baars, "Biomonitoring with the Buzzard Buteo buteo in the Netherlands: heavy metals and sources of variation," Journal of Ornithology, vol. 137, no. 3, pp. 295-318, 1996.

[3] E. Carpane, R. Serra, and G. Isani, "Heavy metals in some species of waterfowl of northern Italy," Journal of Wildlife Diseases, vol. 31, no. 1, pp. 49-56, 1995.

[4] M. Fasola, P. A. Movalli, and C. Gandini, "Heavy metal, organochlorine pesticide, and $\mathrm{PCB}$ residues in eggs and feathers of herons breeding in northern Italy," Archives of Environmental Contamination and Toxicology, vol. 34, no. 1, pp. 87-93, 1998.

[5] A. Zaccaroni, M. Cavaliere, B. Naso, and G. Andreani, "Essential $(\mathrm{Cu}-\mathrm{Zn})$ and toxic $(\mathrm{Cd}-\mathrm{Pb})$ metal levels in birds of prey from Campania and Calabria regions," Atti della Società Italiana delle Sienze Veterinarie, vol. 54, pp. 325-326, 2000.

[6] S. Gragnaniello, D. Fulgione, M. Milone, O. Soppelsa, P. Cacace, and L. Ferrara, "Sparrows as possible heavy-metal biomonitors of polluted environments," Bulletin of Environmental Contamination and Toxicology, vol. 66, no. 6, pp. 719726, 2001.

[7] C. Leonzio and A. Massi, "Metal biomonitoring in bird eggs: a critical experiment," Bulletin of Environmental Contamination and Toxicology, vol. 43, no. 3, pp. 402-406, 1989.

[8] E. Alleva, N. Francia, M. Pandolfi, A. M. De Marinis, F. Chiarotti, and D. Cantucci, "Organochlorine and heavy metals contaminats in wild mammals and birds of UrbinoPesaro province, Italy: an analytic overview for potential bioindicators," Archives of Environmental Contamination and Toxicology, vol. 51, no. 1, pp. 23-134, 2006.

[9] L. Campanella, M. E. Conti, F. Cubadda, and C. Sucapane, "Trace metals in seagrass, algae and molluscs from an uncontaminated area in the Mediterranean," Environmental Pollution, vol. 111, no. 1, pp. 117-126, 2001. 
[10] A. Anastasio, R. Caggiano, M. Macchiato, et al., "Heavy metal concentrations in dairy products from sheep milk collected in two regions of southern Italy," Acta Veterinaria Scandinavica, vol. 47, no. 1, pp. 69-74, 2006.

[11] A. J. Garcia-Fernandez, J. A. Sanchez-Garcia, P. JimenezMontalban, and A. Luna, "Lead and cadmium in wild birds in southeastern Spain," Environmental Toxicology and Chemistry, vol. 14, no. 12, pp. 2049-2058, 1995.

[12] P. Licata, D. Trombetta, M. Cristani, et al., "Levels of "toxic" and "essential" metals in samples of bovine milk from various dairy farms in Calabria, Italy," Environment International, vol. 30, no. 1, pp. 1-6, 2004.

[13] G. Dugo, L. La Pera, A. Bruzzese, T. M. Pellicanò, and V. L. Turco, "Concentration of Cd (II), Cu (II), Pb (II), Se (IV) and Zn (II) in cultured sea bass (Dicentrarchus labrax) tissues from Tyrrhenian Sea and Sicilian Sea by derivative stripping potentiometry," Food Control, vol. 17, no. 2, pp. 146-152, 2006.

[14] L. La Pera, S. Lo Curto, A. Visco, L. La Torre, and G. Dugo, "Derivative potentiometric stripping analysis (dPSA) used for the determination of cadmium, copper, lead, and zinc in Sicilian olive oils," Journal of Agricultural and Food Chemistry, vol. 50, no. 11, pp. 3090-3093, 2002.

[15] E. Imparato, M. Esposito, G. De Grado, L. Grasso, G. Oliviero, and F. Maddaluno, "Livelli di Piombo e Cadmio, quali indicatori ambientali, nel latte in aziende zootecniche dell'Irpinia," Latte, vol. 24, p. 106, 1999.

[16] J. Burger and M. Gochfeldf, "Metals in albatross feathers from Midway Atoll: influence of species, age, and nest location," Environmental Research A, vol. 82, no. 3, pp. 207-221, 2000.

[17] R. J. Kendall, T. E. Lacher Jr., C. Bunck, et al., "An ecological risk assessment of lead shot exposure in non-waterfowl avian species: upland game birds and raptors," Environmental Toxicology and Chemistry, vol. 15, no. 1, pp. 4-20, 1996.

[18] A. M. Scheuhammer and S. L. Norris, "The ecotoxicology of lead shot and lead fishing weights," Ecotoxicology, vol. 5, no. 5, pp. 279-295, 1996.

[19] L. N. Locke and M. Friend, "Lead poisoning of avian species other than waterfowl," in Lead Poisoning in Waterfowl, D. J. Pain, Ed., pp. 19-22, IWRB Special Publication 16, Slimbridge, UK, 1992.

[20] J. Burger, "Metals in avian feathers: bioindicators of environmental pollution," Reviews in Environmental Toxicology, vol. 5, pp. 203-311, 1993.

[21] T. Dauwe, L. Bervoets, R. Blust, R. Pinxten, and M. Eens, "Can excrement and feathers of nestling songbirds be used as biomonitors for heavy metal pollution?" Archives of Environmental Contamination and Toxicology, vol. 39, no. 4, pp. 541$546,2000$.

[22] D. R. Thompson, "Metal levels in marine vertebrates," in Heavy Metals in the Marine Environment, R. W. Furness and P. S. Rainbow, Eds., pp. 143-182, CRC Press, Boca Raton, Fla, USA, 1990.

[23] J. K. Nicholson, "The comparative distribution of zinc, cadmium and mercury in selected tissues of the herring gull (Larus argentatus)," Comparative Biochemistry and Physiology C, vol. 68, no. 1, pp. 91-94, 1981.

[24] R. W. Furness, "Cadmium in birds," in Environmental Contaminants in Wildlife, W. N. Beyer, G. H. Heinz, and A. W. Redmon-Norwood, Eds., pp. 389-404, CRC Press, Boca Raton, Fla, USA, 2001. 

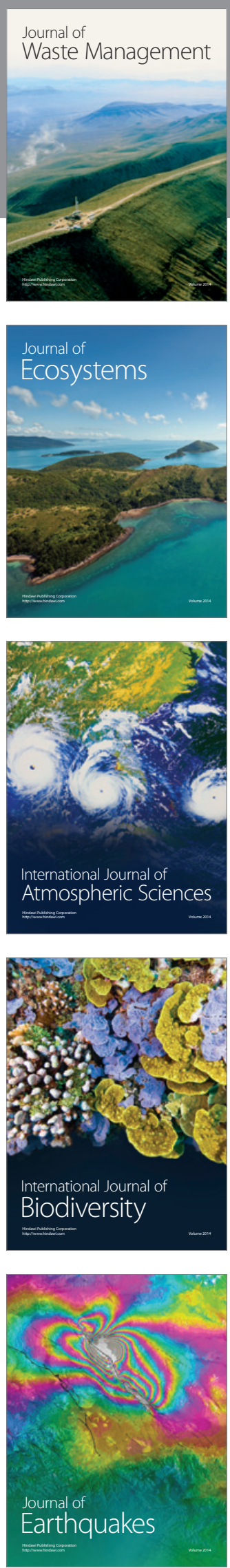
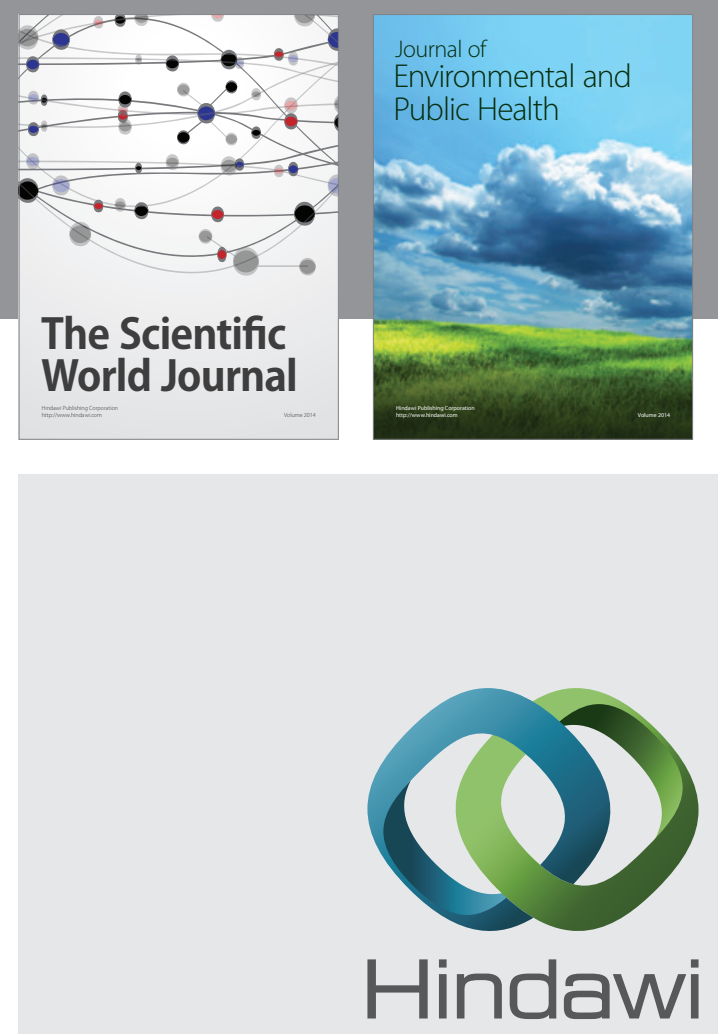

Submit your manuscripts at

http://www.hindawi.com
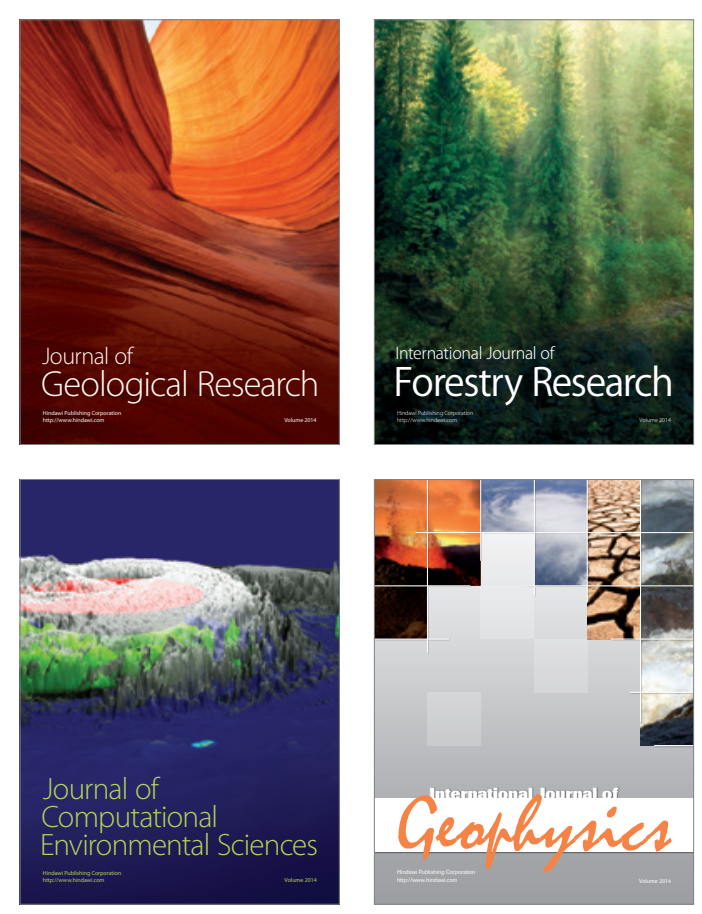
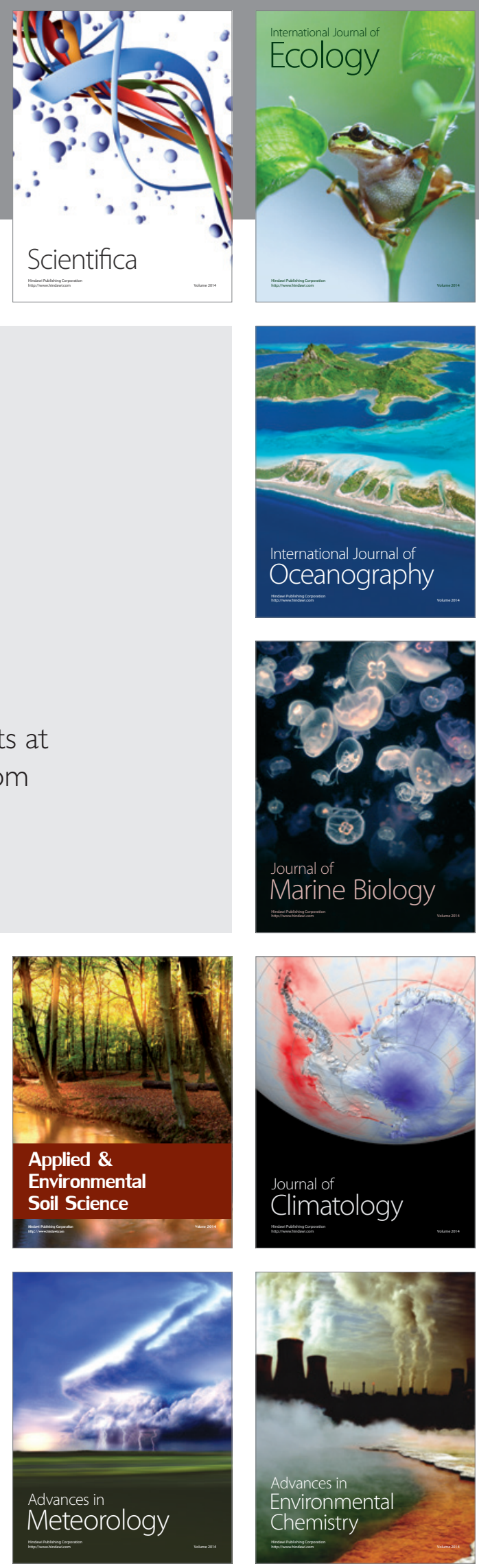